Article

\title{
The Calls for Universal Social Protection by International Organizations: Constructing a New Global Consensus
}

\author{
Lutz Leisering \\ Department of Sociology, Institute for World Society Studies, Bielefeld University, 33615 Bielefeld, Germany; \\ E-Mail: lutz.leisering@uni-bielefeld.de
}

Submitted: 19 October 2019 | Accepted: 24 February 2020 | Published: 18 March 2020

\begin{abstract}
Universalism has become a lead idea of global social politics, and of global social security in particular, first voiced in the Universal Declaration of Human Rights of 1948 and renewed in recent calls for "Social Security for All" and "Universal Health Coverage," and in the Global Partnership for Universal Social Protection to Achieve the Sustainable Development Goals launched by the World Bank and the International Labour Organization in 2016. This article analyses the idea of a universal right to social protection, as recently articulated by international organizations. According to J. W. Meyer's neo-institutionalist theory of world society (Krücken \& Drori, 2009; Meyer, 2007), universalism is a world-cultural norm, and international organizations are proponents of world culture. This article is based on the assumption that the meaning of universalism is not fixed, but that international organizations construct the norm in changing ways to secure worldwide acceptance and applicability, considering that states have very diverse socio-economic conditions and socio-cultural backgrounds. Accordingly, the article analyses how international organizations construct the cultural idea of universalism as well as institutional models of universal social protection. The finding is that the recent calls for universalism represent a new interpretation of universalism that refers to individual entitlements to benefits rather than collective development, and that this global consensus was reached by constructing the norm in a way to leave room for interpretation and adaptation. However, the price of consensus is the attenuation of the norm, by allowing particularistic interpretations and by weakening the content of the right to social protection. The article also seeks to explain the rise of the new global consensus and identify its limitations.
\end{abstract}

\section{Keywords}

human rights; international organizations; social policy; social protection; social rights; social security; universalism

Issue

This article is part of the issue “'Universalism' or 'Universalisms' in Social Policies?” edited by Monica Budowski (University of Fribourg, Switzerland) and Daniel Künzler (University of Fribourg, Switzerland).

(C) 2020 by the author; licensee Cogitatio (Lisbon, Portugal). This article is licensed under a Creative Commons Attribution 4.0 International License (CC BY).

\section{Introduction: The Global Call for a Universal Right to Social Protection}

Universalism is a guiding idea of modernity (Parsons \& Shils, 2001) or even of world culture (Krücken \& Drori, 2009), first laid down in international law in the Universal Declaration of Human Rights of the United Nations (UDHR; UN, 1948), which includes social rights, and confirmed in the International Covenant on Economic, Social and Cultural Rights (ICESCR; UN, 1966). The UDHR posits the basic equality of all human beings "in dignity and rights" (UN, 1948, article 1). However, well into the 1990s, the "right to social security" for "everyone," as laid down in article 22 of the UDHR and in article 9 of the ICESCR, had not led to policies that seek to establish entitlements to social protection benefits for everybody. The International Labour Organization (ILO) had mainly pushed for spreading social insurance, which in the global South only applies to a minority of workers in the formal, mostly urban sector of the economy.

As late as around 1980, and more forcefully in the 2000 s and 2010s, global initiatives for extending the coverage of social security beyond privileged groups took shape. International organizations have been renewing 
the idea of universalism by calling for extending public services to all persons in all countries in the world, such as "Health for All" (World Health Organization [WHO], 1979), "Education for All" (UNESCO, 1982), "Social Security for All" (ILO, 2001, 2003), and "Universal Health Coverage" (UHC2030, 2019; UN, 2012, 2017). Recommendation 202 by the ILO on Social Protection Floors (ILO, 2012) and the 2030 Agenda for Sustainable Development (UN, 2015) also include calls for extending coverage, "leaving no one behind" (UN, 2015). The Global Partnership for Universal Social Protection to Achieve the Sustainable Development Goals, launched by the World Bank and the ILO in 2016 (Rutkowski \& Ortiz, 2016; USP2030, 2019), eventually generalized and consolidated the call for universalism.

In the global North, universalism has been part of the self-description of the welfare state since WWII, particularly among the Nordic countries (Kildal \& Kuhnle, 2005). In global arenas, all major international organizations subscribe to the idea of universalism, but some nationalist, authoritarian, and theocratic regimes have been questioning the idea, as do some intellectuals in democratic societies who view universalism as a late colonial or patriarchal Western ideology. Social security is both a lead idea (Kaufmann, 2012, Chapter 5) and the largest field of social policy. Since around the 2000s, the kindred term "social protection" has also become common. I use the two as interchangeable.

This article seeks to make sense of the recent global calls for universalism by international organizations: what concept of universalism underlies the calls, how do international organizations construct the idea of universalism to secure a worldwide consensus on and applicability of the idea of universalism in a socio-economically and socio-culturally heterogeneous world?

This article is an empirical and conceptual exploration, based on a first screening of documents, and on results of the FLOOR project (www.floorcash.org; see also Leisering, 2019a) on the changing views of international organizations on social protection since the 1990s (von Gliszczynski, 2015), the changing interpretation of social human rights since 1948 (legal branch of the FLOOR project; Davy, 2013, 2014), and the spread of social cash transfers in the global South. To my knowledge, there is only one empirical study of the calls by international organizations for universalism in social protection, by Shriwise, Kentikelenis, and Stuckler (in press), who cover five fields of social protection and argue that universalism is more than just talk; it is a "policy trend" which includes the introduction of new policy instruments.

The article focuses exclusively on ideas, not on actual policies, politics, or policy outcomes. However, from a constructivist sociology of knowledge perspective, I analyse ideas as part of policy paradigms and paradigm shifts. Moreover, the focus is on international organizations, not on national governments and their policies.

The next section is on data and methods, while Section 3 presents the theoretical framework and spec- ifies the research questions. Section 4 traces earlier interpretations of universalism and identifies the origins of the new interpretations that show in the recent calls by international organizations. Section 5 maps the variety of institutional models of universal social protection constructed by international organizations. Section 6 presents the constructions of the cultural idea of universalism in social protection, by which international organizations seek to establish universalism as a globally consensual principle. Section 7 describes the pitfalls to which the politics of universalism in social protection are liable. A conclusion follows.

\section{Data and Methods}

The article is based on an exploratory qualitative content analysis of the calls for universal social protection and on results from the FLOOR project, which draws on the Sociology of Knowledge Approach to Discourse (SKAD; von Gliszczynski, 2015), applied to documents of international organizations, and on a legal analysis of human rights documents (Davy, 2014, 2015). FLOOR has unique self-constructed exhaustive data sets.

The content analysis traces, among others, references to "universal," "universalistic," "universalism," or "universality," to "all" (relating to persons or countries), "everyone," and "no-one" (as in "leaving no-one behind"). Actors may refer explicitly to "universalism" or "universality," or to terms from the semantic field of universalism, especially "inclusive(ness)" (see, e.g., UN, 2018, 2002, para. 13; World Bank, 2012). From the angle of interpretive sociology, the article assumes that the meaning of the concept of universalism (and of other concepts) is not fixed, but that the concept is "constructed"-interpreted, defined, composed, framed, or even created-by actors, and that constructions change over time.

A variety of documents are relevant to the study of universalism:

- Global calls and campaigns for universal social protection;

- Human rights declarations and covenants under the UN, which can also be seen as calls for universalism;

- Major documents like Recommendation 202 on Social Protection Floors (ILO, 2012) or the 2030 Agenda for Sustainable Development of the UN (2015), which have a broader scope, but rank universalism among their key principles;

- Other general documents, such as the World Bank's Social Protection and Labor Strategy 2012-2022 (World Bank, 2012), which also have references to universalism (through "inclusion").

In addition to these more declamatory documents, related operative documents produced by the secretariats and committees of the organizations also matter. 
International organizations are only one variety of what Orenstein (2008, p. 42) calls "transnational actors," that is, actors that need not be international in a constitutional sense but operate in multiple nation-states. Transnational actors in this sense include national development organizations like the German GIZ (Deutsche Gesellschaft für Internationale Zusammenarbeit), global epistemic communities, social movements, and policy entrepreneurs like the German consultant Bernd Schubert. The analysis extends to these "transnational actors," even if for convenience, I speak of "international organizations."

\section{Theoretical Framework: Welfare Internationalism and World Culture}

The theoretical framework of this article includes concepts from sociology, global social policy research, International Relations, and, above all, from neoinstitutionalist world society theory and international law.

The 1940s were a decade of "welfare internationalism" (Kaufmann, 2012, Chapter 4), that is, international organizations increasingly took to social issues, as reflected, among others, in the Atlantic Charter of 1941, the ILO Declaration of Philadelphia of 1944, the UN Charter of 1945, and the UDHR of 1948. All these documents have an explicitly universal scope. Bob Deacon, the founding father of global social policy as a research field, saw the 1990s as a further formative decade of global social policy, positing a "socialization" of global politics, i.e., "social" issues were gaining weight on global agendas which had been dominated by military and security matters and by economic issues (Deacon, Hulse, \& Stubbs, 1997, p. 3). Since that time, international organizations have increasingly become social policy actors, and international organizations that had been concerned with social issues before have extended their domains.

The bourgeoning literature on global policy diffusion has provided ample evidence that ideas and models of international organizations may feed into domestic policies (e.g., Böger \& Leisering, 2020; Leisering, Liu, \& ten Brink, 2017; Orenstein, 2008; Strang \& Chang, 1993; Usui, 1994). Therefore, it makes sense to investigate ideas advanced by international organizations. In the global social policy literature, reference is often made to great ideologies like neo-liberalism, juxtaposed with socialdemocratic or progressive thinking (e.g., Deacon, 2007). There is less literature on more specific ideas, especially those that cut across policy areas. For example, socialscientific analyses of social human rights tend to focus on (insufficient) implementation, rather than analysing the (changing) meaning and interpretation of the rights (e.g., Deacon, 2007, pp. 136-137). This article focuses on a specific global idea, universalism, which cuts across policy areas and common ideologies, and on the interpretation of this idea by global actors.

According to Orenstein (2008), an International Relations scholar, international organizations are "knowl- edge actors," and "proposal actors" in particular (Orenstein, 2008, p. 57), that is, they design and seek to spread specific models of social policy. International organizations fall into representative assemblies of the member states, which govern the organization, and secretariats that do the operative work, such as the International Labour Office within the ILO (Barnett \& Finnemore, 2004). The secretariats often have considerable weight and act in relative autonomy. While the representative assemblies voice more general ideas by way of declarations, the secretariats engage more in designing models, and the two sides may not easily align with each other. In the case of the UN as a social human rights actor, the Economic and Social Council (ECOSOC) assumes an operative role, e.g., by issuing General Comments on selected human rights clauses. International organizations also differ by their mandates. The organizations may attend to designated groups like older persons (HelpAge International) or children (UNICEF), they may cover designated fields like labour (ILO) or food (Food and Agriculture Organization, FAO) or address specific aspects like development (World Bank). We can expect that the mandate of an international organization influences the way the organization conceives of universalism.

Sociological world society theory posits a rising global consciousness and a shared world culture, unlike (or rather complementing) socio-economic theories of globalization (Meyer, 2007, pp. 262-263). "World culture" denotes globally shared ideas, institutional models, and "scripts," which pervade organizations, states, and the individual life course. Meyer holds that world culture took off in the 1940s, in response to the "colossal disaster of World War II" (Krücken \& Drori, 2009, p. 199). Social issues were part of world culture right from the beginning, as welfare internationalism. The most general elements of world culture include universalism, individualism, rationalism, and social progress (Krücken \& Drori, 2009). World-cultural models include, e.g., school curricula, constitutions, and human rights. Human rights are the only global codification of citizenship in all its dimensions, civil, political, and social (Kaufmann, 2012, p. 120).

World society theory conceives of international organizations as key proponents of world culture, as "objective disinterested others" or "rationalized others," who-in the absence of a global democracy-gain legitimacy by advocating universal, world cultural values rather than articulating sectional interests (Krücken \& Drori, 2009, pp. 186, 188). States subscribe to worldcultural ideas in order to pose as good states, even if they cannot or do not want to implement the norms (strategic "decoupling" or "loose coupling"; Krücken \& Drori, 2009, pp. 181-183). The modern nation-state is a world-cultural model, and, at the same time, a key agent of world culture (Krücken \& Drori, 2009, Chapter 8). Furthermore, Meyer assumes expansionist dynamics of world culture, including a growing awareness and articulation of social problems (Krücken \& Drori, 2009, p. 199). 
Universalism under the UN human rights framework means that the rights hold for all persons, all places, and at all times (Davy, 2015, p. 199). From the perspective of Meyer's theory, "place" above all means "nation-state." Legally, the states are the addressees of UN human rights declarations. This helps to disentangle two facets of the norm of "universalism" in social protection that are intertwined: all states should recognize the right to social protection (universal validity of the right as a cultural idea); and in each country, social protection programmes should cover all persons or citizens ("universal social protection" as an institutional model of social policy). The term "model" does not denote a concrete institution or programme, but a simplified cognitive and normative blueprint, that is, it is an idea, too. I assume that international organizations engage with both types of ideas, as suggested by Orenstein and Meyer.

I argue that Meyer tends to take the elements of world culture as given and unchangeable, at least in his research practice. He and associates primarily investigate the implementation of elements of world culture, e.g., the spread of human rights across states, rather than the creation and the changing construction of the elements. In contrast, I argue that world culture is socially constructed by and negotiated among actors and is therefore variable. As a consequence, global (and national) actors may develop very different understandings of these norms and ideas. From this point of view, the spread of world culture is not only about implementation (coupling/decoupling), but about interpretation among international organizations (and by national actors).

Consensus on the idea of universalism cannot be taken for granted, considering that there are around 200 countries in the world that differ considerably in socioeconomic and socio-cultural terms. Davy (2015) challenges the widespread assumption that universalism as a global principle was established in 1948 in the UDHR. She even speaks of universalism as a "myth" (Davy, 2015, p. 200). Universalism as proclaimed in the UDHR, she argues, has little substance, it is expressed in abstract wordings that remain open for diverse understandings, including particularistic interpretations. "It could be that a right is universal precisely when it can be interpreted in particularistic terms in many respects" (Davy, 2015, p. 229; author's translation). Based on an in-depth study of UN documents from 1946 to 1948, Davy finds that in the preparation of the UDHR, the idea of universalism was subject to protracted controversies among member states. She argues that human rights universalism of any substantial kind is a process. In the decades after the UDHR, negotiations in UN human rights committees gradually filled the broad label of universalism with substance, to eventually achieve a degree of convergence among member states. It would be more appropriate to speak of universalisation than universalism.

The difficulties of achieving consensus also affect the recent calls for universalism in social protection. Accordingly, the article pursues three research questions regarding the calls: First, how do international organizations construct the general cultural idea of universalism in social protection to enable worldwide acceptance, considering that the countries in the world have very diverse socio-cultural backgrounds? In other words: How do global actors navigate between the claims of universalism and particularism (see Section 6)? Second, how do international organizations translate the general idea of universalism into specific institutional models (of universal social protection) in view of enabling worldwide applicability, considering the diversity of socio-economic conditions and of national welfare traditions (see Section 5)? States have different cultures of welfare, rooted in distinct traditions of family, of statehood, and of perceptions of social problems, which are shaped by religious and moral traditions. Third, what factors made for the recent rise of the calls for universalism in social protection, and why did these calls come so late, decades after the UDHR? What is new about the interpretation of universalism voiced in the recent calls (see Section 4)?

\section{From Developmental Universalism to Entitlement Universalism: The Origins of the Recent Calls for Universalism}

Explaining the recent rise of calls for universalism in social protection is a research desideratum. Earlier research by FLOOR on changing global ideas at least offers a partial explanation, by identifying an ideational window of opportunity for the new interpretation of universalism. In the 1990s, a window began to open, through three fundamental changes in global discourses, all of which amounted to an individualisation of guiding concepts of global policy, namely development, social human rights, and poverty. These discursive changes were conducive to the new interpretation of universalism.

First, development (Leisering, 2019a, pp. 257-260; von Gliszczynski, 2015, Chapter 4.2). Well into the 1990s, a collective concept of development had prevailed, with an emphasis on structural policies relating to global terms of trade, macroeconomic policies, and the construction of infrastructure (Koehler, 2015). This concept had a universalistic thrust, but in collective rather than individualistic terms (developmental universalism): Advancing welfare through economic growth was to benefit growing sections of the population in the middle and long term, while individual entitlements to welfare benefits, geared to specified individual needs here and now, were secondary or even residual. Developmental universalism reflects the idea of "growth-mediated security," which is driven by markets, while universalism of individual entitlements reflects the idea of "support-led security" (Drèze \& Sen, 1991, p. 22).

From the 1990s, the idea of development changed, not only to pro-poor growth but to growth by the poor: The poor were newly conceptualised as potential agents of economic growth, contributing to development-if supported by welfare benefits. In this way, social pro- 
tection in the sense of individual entitlements to benefits became part and parcel of development policy, beyond the narrow confines of contributory social insurance. Entitlement universalism came to complement developmental universalism.

Second, poverty. Up to the 1990s, a collective concept of poverty had prevailed. Fighting poverty meant to raise national GDP and the overall standard of living. Poverty referred to countries rather than to individuals living in poverty (Berten \& Leisering, 2017, pp. 154-156). But in 1990, an individualized measure of global poverty was introduced, the 1\$-a-day line (World Bank, 1990, pp. 27,139$)$. This was the "first serious attempt to count the world's poor using a common measure" (Hulme, 2015 , p. 34). The new measure was associated with an individualization of poverty policies (Leisering, 2019b), which included direct welfare benefits to the poor.

Third, human rights (Davy, 2013, 2014). Well into the 1990s, article 9 of the ICESCR on the right to social security and article 11 on the right to an adequate standard of living had been mainly interpreted in collective terms, either developmental or socialist (UN, 1966). According to a socialist understanding, social security and livelihoods were embedded in the socialist organization of production. In the collective understandings of rights, individual entitlements to benefits were secondary or even redundant. As late as the 1990s, an interpretation of social rights as individual entitlements to benefits came to prevail, as familiar under post-WWII Northern welfare states. Nowadays, we take an individualized understanding of social rights for granted, but in historical perspective it is rather recent. Moreover, the human rights laid down in the UDHR had generally remained dormant for decades, to become more influential in global discourses only from the 1990s.

The individualisation of the three guiding conceptsdevelopment, social human rights, poverty-challenged the dominance of the concept of developmental (or socialist) universalism, suggesting the concept of entitlement universalism which underlies the recent calls for universalism in social protection. The world cultural principle of universalism was wedded to another world cultural principle, individualism. The individualized notion of universalism marked a thorough-going paradigm shift (or third order policy change, as defined by Hall, 1993) in development policy and in poverty policy (Leisering, 2019a, p. 265): a new problem definition (individual poverty), new discursive frames (individualized concepts of development, with the poor as agents, and of human rights), and a new instrument (social cash transfers to the poor). The new paradigm has established a new global consensus (for this term see also ILO, 2001) in the fields of social protection and development policy. The key call for universalism (Rutkowski \& Ortiz, 2016; USP2030, n.d., 2019) explicitly refers to the new discursive frames by highlighting the collective use of universal social protection-fostering economic growth, productivity, and political stability as well as human rights
(USP2030, n.d.). Similarly, the ILO (2003) aims to "raise awareness worldwide about the role of social security in economic and social development." "Universality" is part of a "common understanding among UN agencies" about a "human rights based approach to development cooperation" (United Nations Sustainable Development Group, 2003; for health see WHO, 2017).

By contrast, Shriwise et al. (in press) maintain that the calls for universalism do not indicate a paradigm change in global policy but draw on dominant norms. However, their window of observation starts as late as 2005, when the paradigm change had already taken place. The supporting statement by von Gliszczynski (2015) they quote refers to the time from 2008 when consensus on social cash transfers was already established.

\section{Constructing Institutional Models of Social Protection: From Universalism to Universalisms}

The global calls for universalism in social protection issued by international organizations testify to the assumptions of world society theory (Krücken \& Drori, 2009; Meyer, 2007) and International Relations (Orenstein, 2008). By issuing these calls, international organizations explicitly legitimize themselves by reference to a fundamental world cultural idea. More specifically, by devising models of universal social protection, international organizations also act as proposal actors, in view of spreading the models worldwide, with states as immediate addressees. Furthermore, the rise of the calls testifies to the expansionist dynamics of world culture, by extending the idea of universalism to the field of social protection, interpreted as entitlement universalism. This section inquires how institutional models of universal social protection were constructed in a way to be applicable to very diverse socio-economic and socio-cultural settings (see Table 1 for models and proponents). Proponents often include more than one model in their documents.

The core of universalism regarding models of social protection, as articulated in the calls by international organizations, is coverage (see, e.g., USP2030, 2019): full coverage of all persons by social protection programmes. Even this seemingly clear-cut operationalization of universalism is open to interpretation: Who is "all"? And universalism of what? (Coverage by what?)

Who is "all"? The unit of reference is often vague: "everyone, as a member of society," or "all people" (USP2030, n.d.). Early calls retain the older reference of social protection to workers rather than citizens, speaking about "working people, particularly in the informal economy" (ILO, 2003) or "the formal and informal working population" (UN, 2002, No. 52(c)). The Madrid International Plan of Action on Ageing refers to an "inclusive society for all ages" (UN, 2002, para. 13). The ILO (2003) also speaks of the countries' "citizens," matching the remit of UN human rights, the states. It is often left open if migrants are to be included, but USP2030 (n.d.) names migrants explicitly. 
Who needs to be included to cover "all" persons? For the ILO (2003) it is mostly informal workers, since they are not covered by social insurance. Later calls name a range of other groups, seen as left behind, such as women, children, persons with disabilities, indigenous peoples, minorities (USP2030, n.d.) or, relating to health, "the most vulnerable" (UN, 2017). The 2030 Agenda for Sustainable Development stipulates to "reach the furthest behind first" (UN, 2015, No. 4). All these groups may be positively discriminated in the context of progressive universalism (see Section 6). Regarding countries, the ILO (2003) only refers to developing countries.

Universalism of what? When speaking about universal coverage, actors may refer to welfare provisions, to entitlements to benefits, and to access to social services.

Many documents call for setting up welfare programmes and providing benefits, but not necessarily for individual rights or entitlements. The World Bank, for example, while not rejecting rights, in most documents simply does not mention rights, e.g., when conceiving of social safety nets for the poor (World Bank, 2018). The Social Protection Floors (ILO, 2012) call for "guarantees" rather than rights. I call these approaches provision universalism, in contradistinction to entitlement universalism, which emphasizes the rights character of provisions (see similarly Leisering, 2019a, pp. 142-143). USP2030 exemplifies the latter.

The third variety, access universalism, applies to social services in particular (but also to income security; see, e.g., ILO, 2003). Related policies seek to set up infrastructure to ensure that all citizens, including, e.g., persons living in remote areas or persons with disabilities, have access to delivery agencies like hospitals, nursing homes, and advice centres. Having access to services is not identical with having entitlements to services. Entitlements relate to law and legal regulations, while access depends on social space and the organization of service delivery. Proclaiming access universalism need not go along with bestowing entitlements on citizens, rather it is about how dense the social infrastructure ought to be. This technocratic approach eases the challenge of universalism. The emphasis on building social infrastructure (Gough, 2019) reflects a collectivist interpretation of social rights. In the field of health services, calls for universalism tend to lean towards provision universalism and access universalism (e.g., UHC2030, 2019).

Entitlement universalism further ramifies into what I call benefit universalism and protection universalism. Benefit universalism denotes the rare case that everybody is entitled to receipt of benefits, irrespective of need. Strictly speaking, the idea of an unconditional Basic Income (UBI) is the only example. Protection universalism refers to programmes that bestow entitlements on every citizen to receive benefits when affected by a designated contingency.

For most social protection programmes, entitlement universalism means protection universalism (Barrientos \& Hulme, 2008, p. 324; Leisering, 2019a, p. 80). This is obvious for social insurance, which bestows benefits on citizens only if certain risks occur, such as old age, unemployment, work accident, or ill-health. Protection universalism in the case of means-tested social cash transfers, however, is contested. Here, protection universalism means that transfers are only paid in case of poverty, to be ascertained by a means test. From this point of view, even means-tested benefits can be (protection) universal or at least contribute to the overall coverage of social protection in a country. Protection universalism seems to be taken for granted by the calls, as hinted at in "cash transfers for all who need it" (USP2030, n.d.) and in "universal health coverage means all people have access to the health care they need, when and where they need it" (WHO, 2019).

Cutting across the basic forms of universalismprovision universalism, entitlement universalism, access universalism-programme universalism and systemic universalism can be distinguished.

Programme universalism refers to universal coverage by single welfare programmes. Thinking in terms of programme universalism is common in global politics, especially in the calls for "universal" pensions and "universal" child benefits (which in fact are categorical). Programme universalism is less abstract and may make consensus easier. Also, programme universalism is mostly categorical, and thereby particularistic, referring to a designated social group or rather "category" constructed by the programmes. The members of each category are assumed to share certain characteristics relevant to social protection, distinct from other categories. A categorical approach constructs social categories or groups as deserving, underpinned by recourse to theorizations (in the case of children, e.g., by theories about the special needs of children) and cultural linkages (in the case of children, e.g., to the human value of children and the UN Convention on the Rights of the Child of 1989; on theorization and cultural linkages as strategies of spreading policies see Strang \& Meyer, 1993). Life-cycle groups are the most common way of constructing target categories, with two categories standing out: older persons and children. Social cash transfer programmes for these categories have been actively promoted by international organizations with a pertinent mandate, namely by HelpAge International and UNICEF (see the discourse analysis by von Gliszczynski \& Leisering, 2016). In the field of health, calls for non-categorical programmes are more common: UHC2030 (2019) calls for health systems that are accessible to all, "irrespective of socio-economic or legal status."

By contrast, the general calls for universalism like USP2030 tend implicitly or explicitly to refer to systemic universalism, that is, to realizing universal coverage by the joint operation of several social protection programmes in a country. This idea may meet with less acceptance among states, because achieving systemic universalism is more demanding than programme universalism. Systemic universalism requires the design of 
Table 1. Varieties of models of universal social protection.

\begin{tabular}{|c|c|}
\hline & Proponents \\
\hline \multicolumn{2}{|l|}{ Universalism of what? } \\
\hline Provision universalism & $\begin{array}{l}\text { Various actors and documents, including the Social Protection Floors (ILO, 2012), } \\
\text { the ICESCR, article } 12 \text { on health (UN, 1966), UHC2030 (2019), World Bank (2018) }\end{array}$ \\
\hline Entitlement universalism & Human rights organizations (e.g., FIAN, HelpAge International) \\
\hline Benefit universalism & Basic Income Earth Network \\
\hline Protection universalism & $\begin{array}{l}\text { Most actors, explicitly, e.g., ECOSOC (2008, General Comment No. } 19 \text { on the right to } \\
\text { social security); USP2030 (n.d., 2019) }\end{array}$ \\
\hline Access universalism & UN General Assembly (UN, 2012, 2017, Universal Health Coverage) \\
\hline \multicolumn{2}{|l|}{ Universalism by what? } \\
\hline Programme universalism & $\begin{array}{l}\text { HelpAge International, Development Pathways (social pensions); } \\
\text { UNICEF (child benefits); Basic Income Earth Network }\end{array}$ \\
\hline Systemic universalism & $\begin{array}{l}\text { Federal Ministry for Economic Cooperation and Development (2019); } \\
\text { USP2030 (n.d., 2019) }\end{array}$ \\
\hline Categorical universalism & ILO (2012, Social Protection Floors, 2010, Staircase Model) \\
\hline Non-categorical universalism & Global policy entrepreneur Schubert (2018) \\
\hline Mixed universalism & World Bank (Gentilini et al., 2020) \\
\hline
\end{tabular}

a composite architecture of social protection in a country. To this end, links between separate policy communities and constituencies need to be forged, programme administrations need to be coordinated, and an integrated normative framework needs to be designed. Such composite design has a horizontal dimension-including programmes for different groups and different social problems - and a vertical dimension, ranging from lower to higher tiers of social protection.

In the horizontal dimension, systemic universalism is mostly categorically differentiated (categorical universalism), with separate programmes for different categories, as for life-cycle categories in the ILO's model of the Social Protection Floors (ILO, 2012). The USP2030 (2019) envisages a combination of "cash or in-kind benefits, contributory or non-contributory schemes, and programmes to enhance human capital, productive assets, and access to jobs."

In the vertical dimension, the ILO (2010, pp. 19-20), the traditional champion of social insurance, has conceived of a tiered "staircase" model, which has the social floor(s) as bottom tier and social insurance as the mainstay, adding up to universal coverage in the vertical dimension. Other models have both a horizontal and a vertical dimension. The global policy entrepreneur Bernd Schubert (2018, p. 8) conceives of a systemically universal architecture of basic social protection in Sub-Saharan countries, differentiated by degree and kinds of poverty of the addressees (non-categorical universalism). The architecture includes emergency relief, insurance against ill-health, disability, and death of a breadwinner, public works, an education grant, and non-categorical social cash transfers. The three-dimensional "social assistance cube" designed by the World Bank (Gentilini, Grosh,
Rigolini, \& Yemtsov, 2020, p. 21) combines a variety of categorical and non-categorical programmes, including social cash transfers, tied cash benefits (like school fee waivers), benefits in kind, and a small UBI component, adding up to a mixed (categorical/non-categorical) universalism.

Alternatively, universal coverage can also be achieved by way of programme universalism, namely by a single programme that covers all citizens (unlike, e.g., "universal" pensions), like a national health service or a "general social assistance" programme that addresses all citizens purely on the basis of need (ascertained through a means test), irrespective of membership in a designated socio-demographic group (noncategorical programme universalism). A UBI would be a non-means-tested variety of a non-categorical programme that achieves universal coverage. Among international organizations, general social assistance belongs to the consensual models of social cash transfers, but political support is weakest (von Gliszczynski \& Leisering, 2016). The model is not actively promoted by any international organizations, none has a mandate for it. Only Schubert (2018) has been spreading a variety of the model in Sub-Saharan Africa, occasionally supported by UNICEF or other international organizations. In the case of single programmes that cover all citizens the distinction between programme universalism and systemic universalism is blurred.

The UBI looms large in global debates and is particularly advocated by the Basic Income Earth Network (BIEN), but was not designated by any major international organization as a model of basic income protection during the formative years of social cash transfers, the 2000s (Leisering, 2019a, Chapter 4). A recent World 
Bank publication considers a UBI, but only as a possible small building block of the "social assistance cube" (Gentilini et al., 2020, p. 21). Debates on a UBI are decoupled from two major discursive frames of global debates on social protection, namely development and human rights (Leisering, 2019a, p. 364; von Gliszczynski, 2017).

We may conclude that the call for universalism in social protection, even if only in a technical sense of extending coverage, is not as clear-cut as it sounds, and allows for a range of institutional models of universalism. Universalism is an empty mould-Shriwise et al. (in press) similarly speak of a "discursive umbrella" - that can be filled by many programme designs and normative models.

\section{Constructing the Cultural Idea of Universalism in Social Protection: Consensus by Attenuation}

The global spread of institutional models of universal social protection is predicated on a consensus on the cultural idea of universalism in social protection. How has the idea or norm of universalism been constructed to meet with acceptance by very heterogeneous countries?

Considering that the idea of universalism may be foreign to the elites or the ordinary citizens in some countries, international organizations seek to loosen the claims of universalism. In this section, three discursive strategies by which international organizations ease the claims of universalism are identified: phrasing the idea of universalism in abstract or vague terms; offering a broad choice of institutional models of universalism and allowing for national adaptation; and weakening the content of the norm that is to be spread worldwide, the right to social security.

\subsection{Phrasing the Idea of Universalism in Abstract Terms}

The principle of universalism is mostly worded in very general terms, in the UN human rights framework and in the calls by international organizations. This applies to the vague definition of standards (see Section 6.3 below) as well as to the diverse units of reference of universalism (described in Section 5 above). All this makes it easier for actors with different backgrounds to accept universalism and advance particularistic interpretations.

\subsection{Offering Choice and Adaptation of Global Models}

I have shown that international organizations, including international non-governmental organizations (INGOs), and donors propose a range of models. This is likely to raise the applicability of global models of social protection to particular national conditions, leaving choices to the states. In this way, international organizations handle the tension between propagating global "best practices" (e.g., Rio Group, 2006) on the one hand, and holding up the flag of "country ownership" (e.g., World Bank, 2008, p. 382) and discrediting notions of "one size fits all" (e.g., ILO, 2010, p. 21) on the other hand. All main calls by international organizations explicitly emphasize that the states are to choose and adapt the global models, based on an acknowledgement of diverse national conditions:

There are many paths towards universal social protection. Both the ILO and the World Bank fully recognize: national ownership of development processes towards universalism. (ILO \& World Bank, 2015, p. 2; similarly USP2030, n.d.)

There is no universal approach to expanding social security coverage. (ILO, 2003; similarly UN, 2002)

National ownership: Develop social protection strategies and policies based on national priorities and circumstances. (USP2030, 2019; similarly UN, 2002, article 8)

A frequent choice encouraged by sectional governmental and non-governmental international organizations is programme universalism, especially by way of "universal" social pensions and "universal" child benefit, depicted as a step towards systemic universalism. Even within the main types of models - programme universalism, systemic universalism, benefit universalism, protection universalism - there is much variation and choice. For example, categorical systemic universalism can be constructed in many ways, depending on the selection and construction of the categories, their differential treatment, and combinations with non-categorical elements.

The acceptance and applicability of global models is also facilitated by the construction of what I call "meta models." In the case of basic social protection, the universalistic idea of social cash transfers for the poor could only become consensual among international organizations, because during the formative years of the idea of social cash transfers (the 2000s) four particularistic submodels were constructed that reflect domains of international organizations, while the general idea of cash transfers remained an empty meta model (Leisering, 2019a, Chapter 4). In this way, different policy actors could advocate for different interpretations of the core ideas. The multi-pillar model of the World Bank (1994) can also be seen as a meta model, in the field of old-age security.

\subsection{Weakening the Content of the Right to Social Security}

Three avenues of weakening the right to social security can be identified among international organizations: temporalization; vague or absent benefit standards; and recognizing collective interpretations of social rights.

The first avenue of weakening the right to social security, temporalisation of universalism, means allowing for a gradual extension of social protection coverage rather than requiring countries to cover all citizens in one go. 
This "progressive universalism" (UHC2030, 2019) is modelled on the principle of "progressive realization" laid down in the UN human rights framework as acceptable state behaviour (ICESCR, article 2(1); UN, 1966), taken up, e.g., in the ILO's Social Protection Floors (ILO, 2012, Section I, 3). Temporalisation makes the idea of universalism more acceptable, because it is less demanding policy-wise and because it allows for diverse strategies of moving closer to universalism, including decidedly particularistic strategies according to the interests and ideas that prevail in domestic politics. Above all, selected social groups can be prioritized and positively discriminated (see Section 5).

Temporalisation is found in all major calls for universalism: "encourage countries to extend social security to more of their citizens" (ILO, 2003; similarly UN, 2002, para. 52(c)). The Sustainable Development Goals (Goal 1.3; UN, 2015) specify an interim goal: "By 2030, [to] achieve substantial coverage of the poor and the vulnerable." Temporalisation may also be offered as a choice: as a "choice of countries to aim for gradual and progressive realization or immediate universal coverage" (ILO \& World Bank, 2015, p. 2). Temporalisation may also refer to countries as targeted by international organizations: "increase the number of countries that provide universal social protection" (USP2030, n.d.). Instead of extending coverage, temporalisation may also refer to gradually reaching higher standards (of health services; UN, 2002, article 14).

The second avenue refers to leaving benefit standards vague or even doing without standards. Obviously, this makes universalism easier to swallow for the states. In documents on universalism and inclusiveness, international organizations tend to focus on coverage, but remain silent or vague when it comes to the level of benefits or even benefit standards. Remarkably, even minimum standards of social protection play a marginal role in global discourses. Even the UN human rights framework lacks minimum standards in social security (Davy, 2015). In the ICESCR, the benefit level is vaguely definedarticle 11 posits an "adequate" standard of living - and article 9, the shortest in the Covenant, has no standard at all, even though the article encapsulates the human rights core of universal social protection, the right of everyone to social security (UN, 1966). The specification of article 9 was left to the ILO (Davy, 2013, p. S22) and to the states. Similarly, ILO Recommendation 202 on Social Protection Floors delegates benefit standards to the states (ILO, 2012). USP2030 (n.d.) calls for "adequate" cash transfers. In the health sector, the ICESCR (article 12) proclaims "the highest attainable standard," but more specific documents name malleable standards like "safe, quality services and products" (UHC2030, 2019), "essential health services," and "primary health care" (WHO, 2019).

The third avenue of weakening the right to social security is giving weight to developmental universalism and access universalism (emphasizing social infrastructure), which reflect collective interpretations of social rights, as analysed in Sections 4 and 5. Highlighting collective strategies of universalism while attributing a residual role to welfare entitlements, may be applauded by some states in the quest for economic progress.

\section{Pitfalls}

I argue that that the new global consensus on universalism in social protection is liable to pitfalls when turned into policies. Three pitfalls can be distinguished: malleability; residualism; and, closely linked, inequality.

The malleability of the idea of universalism, while enabling the global acceptance of the idea, allows for particularistic interpretations and realizations to be presented under the flag of universalism. The idea of universalism creates an open space in which activists can lobby for the interests of particular groups. Concern of minority groups may eclipse the needs of majority groups. For example, progressive universalism can lead to prioritizations based on sectional attributions of deservingness and powerful lobby groups.

On residualism: Universalistic programmes tend to have indefinite or low benefits, in practice as well as in the policy conceptions of international organizations. The German sociologist Georg Simmel (1908/1965) argued that benefits that accrue to everybody, without stipulating any specific quality or achievement of a person, tend to be low. This may apply to universal benefits. Universalistic social policy, therefore, risks to become residual.

This is closely linked to the issue of inequality. Korpi and Palme (1998) identify a "paradox of redistribution": policies that concentrate their efforts on the poor, are less successful in fighting poverty and inequality. This finding is often taken as an argument against meanstested benefits (social assistance, social cash transfers), but according to Korpi and Palme the paradox of redistribution also applies to universal programmes (here defined as non-means-tested and flat-rate). Universal programmes leave a "space of inequality" (Leisering \& Marschallek, 2010) above basic social protection-a space which the middle classes fill by taking up more generous private and occupational welfare. As a consequence, the middle classes are likely to lose interest in public welfare and diminish their political support; the fiscal space of government will narrow, and the universal programmes will deteriorate:

The solidarity of flat-rate universalism presumes a historically peculiar class structure, one in which the vast majority of the population are the "little people" for whom a modest, albeit egalitarian, benefit may be considered adequate. Where this no longer obtains, as occurs with growing working-class prosperity and the rise of the new middle classes, flatrate universalism inadvertently promotes dualism because the better-off turn to private insurance and to fringe-benefit bargaining...the result is that the won- 
derfully egalitarian spirit of universalism turns into a dualism similar to that of the social-assistance state: the poor rely on the state, and the remainder on the market. (Esping-Andersen, 1990, p. 25)

Generally speaking, universalism is basically an egalitarian notion, but universalistic policies are prone to create social divisions, in several ways. Categorical universalism, which is more common than non-categorical universalism, creates fragmentation and inequalities between social groups. Temporalization of the right to social protection (progressive universalism) excludes certain groups. And the residualist tendency of universalism entails a dualistic structure of stratification, as described by Esping-Andersen in the above quote. According to Korpi and Palme (1998), a multi-tiered ("encompassing") model of social protection (realizing systemic universalism) is more successful in fighting poverty and inequality than universalistic programmes. But substantial inequality would remain. Fighting poverty has been at the centre of global development politics since the Millennium Development Goals of 2000, but in the 2010s, the even bigger challenge of increasing inequality has come to the fore. The idea and practice of universalism is of little avail in reducing inequality beyond alleviating poverty.

\section{Conclusion: A New Global Consensus and Its Limitations}

Universalism seems to be a clearly defined and consensual principle, but on closer examination it turns out that this global norm is subject to diverse and changing interpretations, and that achieving consensus is demanding. The recent calls for universalism in social security by international organizations represent a new, individualistic interpretation of this norm (what I call entitlement universalism), which qualifies collectivist, developmental interpretations that had prevailed well into the 1990s. The new universalism is part of a paradigm shift in global social policy and in development policy. The global consensus on the new universalism could only be achieved because international organizations have left room for diverse interpretations and institutional models: by allowing for less demanding varieties of universalism like provision universalism, access universalism, and programme universalism, and through discursive strategies that attenuate the right to social security.

The malleability of universalism as a world-cultural norm contributes to the unity of world society, by mediating the tension between a unified world culture and the socio-cultural heterogeneity of the world. In political terms, the malleability of the new norm enables coalitions between dissimilar actors, as between the World Bank, the ILO and others under the USP2030. The political utility of open or even vague concepts has been observed by writers for some time (e.g., Luhmann, 1970).

However, the price of consensus is the attenuation of the norm, by allowing particularistic interpretations and by weakening the content of the right to social protection. Moreover, universalism is liable to pitfalls, including the risk of residual universalism and new social divisions, leaving the vast social inequalities in the global South unattended. Furthermore, global migration flows are undermining the territorial state and the status of national citizenship as units of reference for the universalization of social human rights. The increasing fluidity of global labour in an age of digitalization and cyberspace, with new forms like platform work, may also require new ways of providing security "to all people wherever and however they work" (Packard et al., 2019, a World Bank publication). New elements of world culture will be needed to frame such changes.

\section{Acknowledgments}

The article stems from the research project FLOOR-B at Bielefeld University, Germany, part of the wider interdisciplinary research project FLOOR, funded by the German Research Council (Deutsche Forschungsgemeinschaft), and with principal investigator Lutz Leisering (www.floorcash.org). I am indebted to the research team for scholarly exchanges and support. First ideas for the article were presented on 19 December 2018 at the Institute of Sociology, University of Duisburg-Essen, Germany. I also thank the anonymous reviewers, the editors, and Timotheus Brunotte for significant comments which helped to improve the article.

\section{Conflict of Interests}

The author declares no conflict of interests.

\section{References}

Barnett, M., \& Finnemore, M. (2004). Rules for the world. International organizations in global politics. London and Ithaca, NY: Cornell University Press.

Barrientos, A., \& Hulme, D. (2008). Embedding social protection in the developing World. In A. Barrientos \& D. Hulme (Eds.), Social protection for the poor and poorest (pp. 315-330). Basingstoke: Palgrave Macmillan.

Berten, J., \& Leisering, L. (2017). Social policy by numbers. How international organisations construct global policy proposals. International Journal of Social Welfare, 26(2), 151-167.

Böger, T., \& Leisering, L. (2020). A new pathway to universalism? Explaining the spread of "social" pensions in the global South, 1967-2011. Journal of International Relations and Development. https://doi.org/ 10.1057/s41268-018-0152-2

Davy, U. (2013). Social citizenship going international: Changes in the reading of UN-sponsored economic and social rights. International Journal of Social Welfare, 22(S1), S15-S31.

Davy, U. (2014). How human rights shape social citizenship: On citizenship and the understanding of 
economic and social rights. Washington University Global Studies Law Review, 13, 201-393.

Davy, U. (2015). Der "Universalismus" der Allgemeinen Erklärung der Menschenrechte: Die Arbeit am Konsens, 1946-1948 [The "universalism" of the Universal Declaration of Human Rights: Working on consensus]. In B. Heintz \& B. Leisering (Eds.), Menschenrechte in der Weltgesellschaft (pp. 198-235) [Human rights in world society]. New York, NY: Campus.

Deacon, B. (2007). Global social policy and governance. London: Sage.

Deacon, B., Hulse, M., \& Stubbs, P. (1997). Global social policy: International organizations and the future of welfare. London: Sage.

Drèze, J., \& Sen, A. K. (1991). Public action for social security. In E. Ahmad, J. Drèze, J. Hills, \& A. K. Sen (Eds.), Social security in developing countries (pp. 3-40). Oxford: Clarendon Press.

ECOSOC. (2008). General Comment No. 19: The right to social security (art. 9). New York, NY: UN Committee on Economic, Social and Cultural Rights.

Esping-Andersen, G. (1990). The three worlds of welfare capitalism. Cambridge: Polity Press.

Federal Ministry for Economic Cooperation and Development. (2019). A systems perspective on universal social protection. Towards life-long equitable access to comprehensive social protection for all. Bonn: BMZ.

Gentilini, U., Grosh, M., Rigolini, J., \& Yemtsov, R. (Eds.). (2020). Exploring universal basic income: A guide to navigating concepts, evidence, and practices. Washington, DC: World Bank.

Gough, I. (2019). Universal basic services: A theoretical and moral framework. The Political Quarterly, 90(3), 534-542.

Hall, P. (1993). Policy paradigms, social learning, and the state: The case of economic policymaking in Britain, Comparative Politics, 25(3), 275-296.

Hulme, D. (2015). Global poverty: Global governance and poor people in the post-2015 era (2nd ed.). New York, NY: Routledge.

International Labour Organization. (2001). Social security: A new consensus. Geneva: ILO.

International Labour Organization. (2003). Global campaign on social security and coverage for all. International Labour Organization. Retrieved from http://www.ilo.org/public/english/protection/ socsec/pol/campagne/index.htm

International Labour Organization. (2010). Extending social security to all: A guide through challenges and options. Geneva: ILO.

International Labour Organization. (2012). Social Protection Floors Recommendation (R202). Geneva: ILO.

International Labour Organization, \& World Bank. (2015). A shared mission for universal social protection: Concept note. Geneva: ILO and World Bank. Retrieved from https://www.ilo.org/wcmsp5/ groups/public/---dgreports/---dcomm/documents/ genericdocument/wcms_378996.pdf
Kaufmann, F.-X. (2012). European foundations of the welfare state. New York, NY: Berghahn Publishers.

Kildal, N., \& Kuhnle, S. (2005). The principle of universalism: Tracing a key idea in the Scandinavian welfare model. In N. Kildal \& S. Kuhnle (Eds.), Normative foundations of the welfare state: The Nordic experience (pp. 13-33). London: Routledge.

Koehler, G. (2015). Seven decades of "development," and now what? Journal of International Development, 27(6), 733-751.

Korpi, W., \& Palme, J. (1998). The paradox of redistribution and strategies of equality: Welfare state institutions, inequality and poverty in the Western countries. American Sociological Review, 63(5), 661-687.

Krücken, G., \& Drori, G. S. (Eds.). (2009). World society: The writings of John W. Meyer. Oxford: Oxford University Press.

Leisering, L. (2019a). The global rise of social cash transfers: How states and international organizations constructed a new instrument for combating poverty. Oxford: Oxford University Press.

Leisering, L. (2019b). Social cash transfers in the global South: Individualizing poverty policies. In B. Greve (Ed.), Routledge international handbook of poverty (pp. 317-327). London: Routledge.

Leisering, L., \& Marschallek, C. (2010). Zwischen Wohlfahrtsstaat und Wohlfahrtsmarkt: Alterssicherung und soziale Ungleichheit [Between welfare state and welfare market: Old-age security and social inequality]. In H. G. Hockerts \& W. Süß (Eds.), Soziale Ungleichheit im Sozialstaat: Die Bundesrepublik Deutschland und Großbritannien im Vergleich [Social inequality in the welfare state: The Federal Republic of Germany and Great Britain compared] (pp. 89-115). München: Oldenbourg.

Leisering, L., Liu, T., \& ten Brink, T. (2017). Synthesizing disparate ideas: How a Chinese model of social assistance was forged. Global Social Policy, 17(3), 307-327.

Luhmann, N. (1970). Wahrheit und Ideologie [Truth and ideology]. In L. Luhmann, Soziologische Aufklärung [Sociological enlightenment] (pp. 54-65). Opladen: Westdeutscher Verlag.

Meyer, J. W. (2007). Globalization: Theory and trends. International Journal of Comparative Sociology, 48(4), 261-273.

Orenstein, M. A. (2008). Privatizing pensions: The transnational campaign for social security reform. Princeton, NJ: Princeton University Press.

Packard, T., Gentilini, U., Grosh, M., O’Keefe, P., Palacios, R., Robalino, D., \& Santos, I. (2019). Protecting all: Risk sharing for a diverse and diversifying world of work. Washington, DC: World Bank.

Parsons, T., \& Shils, E. A. (2001). Toward a general theory of action. New Brunswick, NJ: Transaction Publishers.

Rio Group. (2006). Compendium of best practices in poverty measurement. Rio de Janeiro: United Nations. 
Rutkowski, M., \& Ortiz, I. (2016). Universal social protection to achieve the SDGs: Launch of the new global partnership for universal social protection to achieve the Sustainable Development Goals. New York, NY: UN, World Bank Group and ILO. Retrieved from https://www.social-protection.org/gimi/gess/ RessourcePDF.action?id=54051

Schubert, B. (2018). Quantitative assessment of the social assistance system in the Kingdom of Eswatini. Mbabane: UNICEF.

Shriwise, A., Kentikelenis, A., \& Stuckler, D. (in press). Universal social protection: Is it just talk? Sociology of Development.

Simmel, G. (1965). The poor. Social Problems, 13(2), 118-140. (Original work published in German in 1908)

Strang, D., \& Chang, P. M. Y. (1993). The International Labour Organization and the welfare state: Institutional effects on national welfare spending, 1960-80. International Organization, 47(2), 235-262.

Strang, D., \& Meyer, J. W. (1993). Institutional conditions for diffusion. Theory and Society, 22(4), 487-511.

UHC2030. (2019). Moving together to build a healthier world. Key asks from the UHC movement. UN high-level meeting on universal health coverage. UHC2030. Retrieved from https://www.uhc2030. org/fileadmin/uploads/uhc2030/Documents/ UN_HLM/UHC_Key_Asks_final.pdf

UN. (1948). Universal Declaration of Human Rights. New York, NY: United Nations.

UN. (1966). International Covenant on Economic, Social, and Cultural Rights. New York, NY: United Nations.

UN. (2002). Political Declaration and Madrid International Plan of Action on Ageing. Madrid: United Nations.

UN. (2012). Global health and foreign policy. (UN General Assembly Resolution A/Res/67/81, 12 December 2012). New York, NY: United Nations.

UN. (2015). Transforming our world: The 2030 Agenda for Sustainable Development. New York, NY: United Nations.

UN. (2017). Global health and foreign policy: Addressing the health of the most vulnerable for an inclusive society. (UN General Assembly Resolution A/RES/72/139, 12). New York, NY: United Nations.

UN. (2018). Promoting inclusion through social protection. Report on the world social situation 2018. New York, NY: United Nations.

UNESCO. (1982). Major programme II: 'Education for all.' Paris: UNESCO. Retrieved from http://unesdoc. unesco.org/images/0005/000539/053978E.pdf

United Nations Sustainable Development Group. (2003). The human rights based approach to development cooperation-Towards a common understanding among UN agencies. New York, NY: UNDG. Retrieved from https://undg.org/wp-content/uploads/
2017/01/The_Human_Rights_Based_Approach_to_ Development_Cooperation_Towards_a_Common_ Understanding_among_UN.pdf

USP2030. (n.d.). Universal social protection 2030: Vision. USP2030. Retrieved from https://www.usp2030.org/ gimi/USP2030.action

USP2030. (2019). Together to achieve universal social protection by 2030: A call to action. USP2030. Retrieved from https://www.usp2030.org/gimi/ RessourcePDF.action ?id=55464

Usui, C. (1994). Welfare state development in a world system context: Event history analysis of first social insurance legislation among 60 countries, 1880-1960. In T. Janoski \& A. M. Hicks (Eds.), The comparative political economy of the welfare state (pp. 254-277). Cambridge: Cambridge University Press.

von Gliszczynski, M. (2015). Cash transfers and basic social protection: Towards a development revolution? Basingstoke: Palgrave Macmillan.

von Gliszczynski, M. (2017). Social protection and basic income in global policy. Global Social Policy, 17(1), 98-100.

von Gliszczynski, M., \& Leisering, L. (2016). Constructing new global models of social security: How international organizations defined the field of social cash transfers in the 2000s. Journal of Social Policy, 45(2), 325-343.

World Health Organization. (1979). Formulating strategies for health for all by the year 2000. Geneva: WHO.

World Health Organization. (2017). UHC2030 International Health Partnership. Global compact for progress towards universal health coverage. Geneva: WHO. Retrieved from https://www.uhc2030.org/ fileadmin/uploads/uhc2030/Documents/About_ UHC2030/mgt_arrangemts__docs/UHC2030_ Official_documents/UHC2030_Global_Compact_ WEB.pdf

World Health Organization. (2019). UN high-level meeting on universal health coverage. World Health Organization. https://www.who.int/news-room/events/ detail/2019/09/23/default-calendar/un-high-levelmeeting-on-universal-health-coverage

World Bank. (1990). World Development Report 1990: Poverty. New York, NY: Oxford University Press.

World Bank. (1994). Averting the old age crisis: Policies to protect the old and promote growth. New York, NY: Oxford University Press.

World Bank. (2008). For protection and promotion. The design and implementation of effective safety nets. Washington, DC: World Bank.

World Bank. (2012). Resilience, equity and opportunity: Social protection and labor strategy. Washington, DC: World Bank.

World Bank. (2018). The state of social safety nets 2018. Washington, DC: World Bank. 


\section{About the Author}

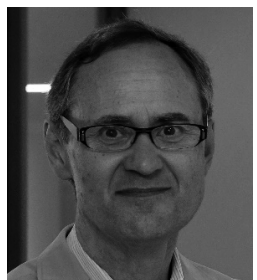

Lutz Leisering is Emeritus Professor of Social Policy at the Department of Sociology, Bielefeld University, Germany, and founding member of the Institute for World Society Studies. He holds a PhD (econ.) from the London School of Economics and has published on social policy in Europe and the global South, especially on old-age security, social assistance, international organizations, and the global diffusion of ideas; his most recent book is The Global Rise of Social Cash Transfers (2019, OUP). He is a Board member of HelpAge Germany. 